\title{
Impact of radiotherapy in head and neck regions on periodontal and oral hygiene
}

\section{conditions}

\author{
Impacto da radioterapia em região de cabeça e pescoço sobre a condição periodontal e de higiene oral \\ Impacto de la radioterapia en cabeza y cuello sobre la condición periodontal y la higiene oral
}

Received: 02/07/2021 | Reviewed: 02/12/2021 | Accept: 02/15/2021 | Published: 02/22/2021

\author{
André Costa Cartaxo \\ ORCID: https://orcid.org/0000-0002-6769-1702 \\ Federal University of Rio Grande do Norte, Brazil \\ E-mail: decocartaxo@yahoo.com.br \\ Liliane Cristina Nogueira Marinho \\ ORCID: https://orcid.org/0000-0002-9289-6582 \\ Federal University of Rio Grande do Norte, Brazil \\ E-mail: liliane_marinho@hotmail.com \\ Davi Neto de Araújo Silva \\ ORCID: https://orcid.org/0000-0002-4292-0118 \\ Federal University of Rio Grande do Norte, Brazil \\ E-mail: davinetoaraujo@yahoo.com.br \\ Natália Teixeira da Silva \\ ORCID: https://orcid.org/0000-0002-1947-6813 \\ Federal University of Rio Grande do Norte, Brazil \\ E-mail: teixeira.nathh@gmail.com \\ Maria de Lourdes Silva de Arruda Morais \\ ORCID: https://orcid.org/0000-0002-2294-3320 \\ Federal University of Rio Grande do Norte, Brazil \\ E-mail: lourd_arruda@ hotmail.com \\ André Luís Dorini \\ ORCID: https://orcid.org/0000-0003-1518-4255 \\ Federal University of Rio Grande do Norte, Brazil \\ E-mail: andredorini@yahoo.com \\ Ana Rafaela Luz de Aquino Martins \\ ORCID: https://orcid.org/0000-0001-7188-4964 \\ Federal University of Rio Grande do Norte, Brazil \\ E-mail: anarafaelaluz@terra.com.br
}

\begin{abstract}
Objective: Evaluate the influence of head and neck radiotherapy dose on periodontal tissue for to understanding of its adverse effects, and consequently to propose strategies to reduce its severity. Methodology: An observational, longitudinal and prospective study with intraoral clinical examinations performed before radiotherapy (T0) and immediately after the end of radiation therapy. The clinical data collected regarding oral and periodontal hygiene conditions were visible plaque index (VPI), gingival bleeding index (GBI), probing depth (PD), gingival recession area, clinical attachment level (CAL), degree of mobility and presence or absence of suppuration. In addition, data such as radiation dose, fractionation and duration of radiotherapy were reported. Results: Fourteen patients were evaluated, of which 11 had periodontitis after the radiotherapy, and 9 had poor oral hygiene conditions after the radiotherapy. Seven of the 11 subjects with periodontitis presented tumors in the oral cavity. There was a decrease in visible plaque index (VPI) and gingival bleeding index (GBI). The research was unable to establish a significant association between radiation therapy and oral hygiene condition and periodontitis. Conclusion: Poor oral hygiene conditions predominated in the sample, which can be associated with the presence of debilitating conditions. Direct radiation on the oral cavity may have an influence on the development of periodontitis. The development of gingivitis only and periodontitis was not influenced by dose, fraction or duration of radiotherapy in the study period.
\end{abstract}

Keywords: Periodontal disease; Periodontitis; Radiotherapy; Squamous cell carcinoma; Head and neck neoplasms. 


\section{Resumo}

Objetivo: Avaliar a influência da dose da radioterapia em cabeça e pescoço no tecido periodontal para a compreensão de seus efeitos adversos e, consequentemente, propor estratégias para redução de sua gravidade. Metodologia: Estudo observacional, longitudinal e prospectivo com exames clínicos intraorais realizados antes da radioterapia (T0) e imediatamente após o término da radioterapia. Os dados clínicos coletados em relação às condições de higiene oral e periodontal foram índice de placa visível (IPV), índice de sangramento gengival (ISG), profundidade de sondagem (PS), área de recessão gengival, nível de inserção clínica (NIC), grau de mobilidade e presença ou ausência de supuração. Além disso, foram relatados dados como dose de radiação, fracionamento e duração da radioterapia. Resultados: Foram avaliados 14 pacientes, dos quais 11 apresentaram periodontite após a radioterapia e 9 apresentaram péssimas condições de higiene bucal após a radioterapia. Sete dos 11 indivíduos com periodontite apresentaram tumores na cavidade oral. Houve uma diminuição no índice de placa visível (IPV) e índice de sangramento gengival (ISG). A pesquisa não foi capaz de estabelecer uma associação significativa entre a radioterapia e as condições de higiene oral e periodontite. Conclusão: As más condições de higiene bucal predominaram na amostra, o que pode estar associado à presença de condições debilitantes. A radiação direta na cavidade oral pode ter influência no desenvolvimento da periodontite. O desenvolvimento de apenas gengivite e periodontite não foi influenciado pela dose, fração ou duração da radioterapia no período do estudo.

Palavras-chave: Doença periodontal; Periodontite; Radioterapia; Carcinoma de células escamosas; Neoplasias de cabeça e pescoço.

\section{Resumen}

Objetivo: Evaluar la influencia de la dosis de radioterapia de cabeza y cuello sobre el tejido periodontal para conocer sus efectos adversos y, en consecuencia, proponer estrategias para reducir su gravedad. Metodología: Estudio observacional, longitudinal y prospectivo con exámenes clínicos intraorales realizados antes de la radioterapia (T0) e inmediatamente después de finalizar la radioterapia. Los datos clínicos recopilados sobre las condiciones de higiene oral y periodontal fueron índice de placa visible (IPV), índice de sangrado gingival (ISG), profundidad de sondaje (PS), área de recesión gingival, nivel de inserción clínica (NIC), grado de movilidad y presencia o ausencia supuración. Además, se informaron datos como la dosis de radiación, el fraccionamiento y la duración de la radioterapia. Resultados: Se evaluaron catorce pacientes, de los cuales 11 presentaron periodontitis después de la radioterapia y 9 tuvieron malas condiciones de higiene bucal después de la radioterapia. Siete de los 11 sujetos con periodontitis presentaron tumores en la cavidad bucal. Hubo una disminución en el índice de placa visible (IPV) y el índice de sangrado gingival (ISG). La investigación no pudo establecer una asociación significativa entre la radioterapia y la condición de higiene bucal y periodontitis. Conclusión: En la muestra predominaron las malas condiciones de higiene bucal, que pueden asociarse con la presencia de condiciones debilitantes. La radiación directa sobre la cavidad bucal puede influir en el desarrollo de periodontitis. El desarrollo de gingivitis solamente y periodontitis no fue influenciado por la dosis, fracción o duración de la radioterapia en el período de estudio.

Palabras clave: Enfermedad periodontal; Periodontitis; Radioterapia; Carcinoma de células escamosas; Neoplasias de cabeza y cuello.

\section{Introduction}

Radiotherapy is a therapeutic modality that uses ionizing radiation as a therapeutic agent against malignant neoplasms, constituting an extremely effective treatment for head and neck tumors, both as a primary modality and as an adjunct to surgery (Bhide, et al., 2010).

The radiation action can be direct or indirect. In direct action, the DNA molecule is cleaved, interfering with the duplication process. In indirect action, water is dissociated into $\mathrm{H}+$ and $\mathrm{OH}-$, and the latter reacts with the DNA bases, interfering with the duplication process. As water represents most of the cell content, the indirect effect is proportionally more important than the direct effect (Krstevska, et al., 2009). Therefore, the ionizing radiation action on nuclear DNA disables cells from multiplying. The cells with high mitotic activity are the most sensitive. The malignant cells in continuous multiplication tend to suffer the main radiation effects (Krstevska, et al., 2009).

The adverse effects of radiotherapy especially affect normal cells which are also constantly replicating or failing to repair DNA damage. Among these cells are those of the oral mucosa epithelium, underlying connective tissue, tooth, periosteum, bone, salivary glands and vessels, resulting in debilitating oral complications, including periodontal damage (Beech et al., 2014). 
Adverse effects in periodontal tissue have been related to a decrease in the blood vessel size and blood supply; increase in collagen production and decrease in the cell number in the underlying connective tissue which can cause periodontal tissue to rupture and thin. The periodontal space becomes larger and Sharpey fibers become disorganized, which favors developing infections (Silverman, et al., 1965; Marques, et al., 2004). In addition, there seems to be exacerbation and immune-inflammatory response dysregulation (Khaw, et al., 2014), and decreased oral hygiene of the patient due to a lack of motivation, hyposalivation and oral mucositis occurrence (resulting from radiotherapy) (Ammajan, et al., 2013).

Few studies have analyzed the radiotherapy effects in the head and neck region on periodontal tissues (Marques, et al., 2004; Hong, et al., 2010; Duarte, et al., 2013; Ammajan, et al., 2013; Khaw, et al., 2014b), and the results of such studies are conflicting. While Marques and Dib (2004), Ammajan et al. (2013) and Khaw et al. (2014) highlighted an increase in the gingival bleeding index (GBI), loss of clinical attachment level (CAL) and gingival recession, Bueno et al. (2013) observed CAL stabilization, and a decrease in the visible plaque index (VPI) and gingival bleeding index (GBI). Ammajan et al. (2013) also noted a drop in the quality of patients' oral hygiene after radiotherapy.

In view of the divergences found in the literature and the possible periodontal changes resulting from radiotherapy, as well as the morbidity to which these patients undergoing treatment with ionizing radiation are continually exposed, this study aimed to assess the influence of head and neck radiotherapy dose on periodontal tissue for to understanding of the adverse effects and, consequently, to propose strategies to reduce its severity.

\section{Methodology}

\subsection{Study design}

This study was approved by the Research Ethics Committee of the Northeriograndense League Against Cancer (number 1296029), and the participants signed a Free and Informed Consent Form (ICF).

This was an observational, longitudinal, prospective study which analyzed the adverse effects on the oral cavity of patients undergoing radiotherapy in the head and neck region. This treatment is already part of the protocol for treating patients with head and neck cancer in the Northeriograndense League against Cancer (LNRCC), and therefore was not the object of the research. The implemented technique was intensive direct observation through intra-oral clinical examinations, with all the obtained data at different intervals being duly registered in specific records and carried out at the Dental Office of LNRCC, in the city of Natal/RN, during the period from 2015 to 2016.

The study sample consisted of 14 patients with malignant tumors in the head and neck region. It was intentionally selected for the evaluated group based on the medical indication about the need for radiotherapy, including patients who would undergo radiotherapy in the head and neck region. Exclusion criteria included: total edentulous patients; patients undergoing antibiotic therapy for less than three months before starting radiotherapy and teeth with a poor prognosis with CAL greater than $7 \mathrm{~mm}$.

The patients were recruited during routine exams and consultations when they are referred to the Dental Clinic within the Hospital Protocol for pre-radiotherapy preparation, in which they are submitted to periodontal therapy with scaling and root planning (SRP) before the radiotherapy treatment. Data collection regarding oral and periodontal hygiene was performed before radiotherapy and immediately after the end of radiation therapy.

The oral hygiene condition was analyzed using the visible plaque index (VPI), categorized as satisfactory (VPI=0 to $15 \%$ ); regular (VPI=16 to 30\%) and unsatisfactory (VPI<30\%), according to the study by Löe (1967). The gingival bleeding index (GBI) 
at the probing of Ainamo and Bay [12] corresponds to the bleeding investigation based on the dichotomy bleeds/does not bleed after 10 seconds of measurement, with a positive (+) score being attributed to a bleeding face, and a negative (-) for not bleeding.

The periodontal condition evaluation was analyzed by performing the gingival bleeding indexes (GBI) of Ainamo and Bay (1975); Probing Depth (PD); Gingival recession; Clinical Attachment Level (CAL), Degree of Dental Mobility and Presence or absence of suppuration.

Gingivitis only and Periodontitis were considered in the study based on the "Classification of Periodontal and Peri-implant Diseases and Practical: Guide and Key Points - 2018" (Steffens, et al., 2018).

The following variables regarding the parameters related to chemotherapy were observed: radiation dose, fractionation and duration of radiotherapy.

Data were collected through a blinded, previously calibrated examiner who underwent intra-examiner calibration training, following the precepts of statistical methods reaching the weighted Kappa $(\kappa) \mathrm{k}=0.82$ for qualitative and quantitative variables.

\subsection{Statistical analysis}

The Wilcoxon test was used for the comparison between the evaluation periods (intra-group comparison). A 95\% confidence interval and a significance level of 5\% ( $\mathrm{p}<0.05)$ were considered. Fisher's exact test was used for the association between variables. Data processing and analysis were performed with SPSS Statistics software for Windows, Version 20.0 (Chicago: SPSS Inc.), and the obtained results were expressed through tables and graphs.

\section{Results}

A total of 16 patients were evaluated after 7 months of research. However, 1 died before the second data collection performed immediately after radiotherapy, and another abandoned treatment, also not returning for the second clinical data collection. Thus, the final group consisted of 14 individuals.

There was a predominance of male patients $(\mathrm{n}=12 ; 85.7 \%)$, while only 2 participants were female $(14.3 \%)$. The patients' ages ranged between 20 and 65 years with most individuals in their fifties and sixties (average age of 46.38 years). Regarding the associated habits, 1 (7.14\%) patient was a smoker, 4 (28.57\%) consumed alcohol, 6 (42.86\%) used tobacco and alcohol, and only 3 $(21.43 \%)$ did not have any associated habits.

Regarding the region of the individuals' primary neoplasia, 8 (57.14\%) had tumors in the oral cavity and $6(42.86 \%)$ had tumors in the other areas of the head and neck region. There was a wide variation ( 3 to 180 months) in terms of the time the patient observed the presence of the tumor; however, the tumor presence was observed by the patient in less than 1 year in most of the sample $(9 ; 64.29 \%)$, while the other 5 patients $(35.71 \%)$ reported the presence of the tumor for at least 2 years.

Patients underwent radiotherapy in different doses and fractionations, resulting in a variety of treatment duration. Thus, $42.9 \%(n=6)$ of the patients suffered treatment interruption, extending the initial forecast of the duration of radiotherapy from 10 to 20 weeks. Side effects were mucositis, nausea and systemic infections.

The VPI analysis showed a median of $39.02 \%$ at baseline and $16.13 \%$ immediately after treatment with radiotherapy. There was no statistically significant difference in this index when comparing the collection times $(\mathrm{p}=0.269)$. The GBI showed a median of $39.46 \%$ at baseline and $26.00 \%$ immediately after radiotherapy, thus presenting a statistically significant difference $(p=0.035)$ (Table 1). 
Table $1-25^{\text {th }}$ and $75^{\text {th }}$ quartiles and medians of the VPI and GBI variables between baseline and after treatment of individuals. Natal/RN, 2016.

\begin{tabular}{cccc}
\hline Time & $\mathbf{Q}_{\mathbf{2 5}}-\mathbf{Q}_{\mathbf{7 5}}$ & Median & $\boldsymbol{p}^{*}$ \\
\hline VPI & $10.93-52.79$ & 39.02 & $\mathbf{0 . 2 6 9}$ \\
Baseline & $6.26-44.93$ & 16.13 & 39.46 \\
After Radiotherapy & GBI & 26.00 & $\mathbf{0 . 0 3 5}$ \\
Bfter Radiotherapy & $20.90-44.90$ & & \\
\hline
\end{tabular}

* - Wilcoxon Test. Source: Statistical Package for the Social Sciences (SPSS 20).

It was possible to determine the patients' oral hygiene condition based on the VPI index. Only 1 (7.1\%) participant had a satisfactory condition in the first collection, while $2(14.3 \%)$ had a regular condition and 11 (78.6\%) had an unsatisfactory oral hygiene condition. In the second data collection, 4 (28.6\%) individuals had satisfactory oral hygiene, $1(7.1 \%)$ had a regular condition and $9(64.3 \%)$ had an unsatisfactory oral hygiene condition.

Regarding the periodontal condition of the participants, the presence of gingivitis only was observed in 5 (35.7\%) patients and periodontitis in $9(64.3 \%)$ patients at the baseline, while $3(21.4 \%)$ presented gingivitis only and 11 (78.6\%) periodontitis immediately after radiotherapy. There was no statistically significant difference $(\mathrm{p}=0.930)($ Table 2$)$.

Table 2 - Periodontal condition before radiotherapy and immediately after the end of radiotherapy treatment. Natal / RN, 2016.

\begin{tabular}{rllclc}
\hline Time & Healthy gum & Gingivitis & Periodontitis & Total & $\boldsymbol{p}^{*}$ \\
\hline Baseline & $0(0,0)$ & $5(35,7)$ & $9(64,3)$ & $14(100,0)$ & $\mathbf{0 , 9 3 0}$ \\
After & $0(0,0)$ & $3(21,4)$ & $11(78,6)$ & $14(100,0)$ & \\
Radiotherapy & & & & \\
\hline
\end{tabular}

* - Wilcoxon Test. Source: Statistical Package for the Social Sciences (SPSS 20).

When relating the presence of gingivitis only and periodontitis after radiotherapy treatment with the duration, fractionation and radiotherapy dose, it was observed that $9(81.8 \%)$ of the participants with periodontitis received radiation doses of up to 60 Gy, while $2(18.2 \%)$ patients with periodontitis received more than 60 Gy of total radiation. The 3 (100\%) patients with gingivitis only received more than $60 \mathrm{~Gy}$ of radiation in their treatment. There was a statistically significant association between gingivitis only and periodontitis $(p=0.027)$.

Regarding fractionation, $72.7 \%(\mathrm{n}=8)$ of individuals with periodontitis received up to 33 sessions of radiotherapy and $27.3 \%(n=3)$ received more than 33 sessions. All $(100 \%)$ patients with gingivitis only received more than 33 radiotherapy sessions. There was also a statistically significant association between gingivitis only and periodontitis $(p=0.055)$. 
Furthermore, 7 (63.6\%) of the members with periodontitis took up to 8 weeks to complete the treatment and 4 (36.4\%) took more than 8 weeks to complete the radiotherapy. For patients with gingivitis only, $1(33.3 \%)$ underwent treatment within 8 weeks, and $2(66.7 \%)$ completed treatment over 8 weeks. There were no statistically significant associations (p>0.05) (Table 3).

Table 3 - Analysis of patients' periodontal condition in relation to the radiotherapy treatment duration, dose and fractionation. Natal / RN, 2016.

\begin{tabular}{|c|c|c|c|c|}
\hline \multirow{2}{*}{ Parameters } & \multicolumn{2}{|c|}{ Periodontal Condition } & \multirow{2}{*}{ Total } & \multirow{2}{*}{$p^{*}$} \\
\hline & Gingivitis & Periodontitis & & \\
\hline \multicolumn{5}{|l|}{ Dose } \\
\hline Up to Gy & $0(0,0)$ & $9(81,8)$ & $9(64,3)$ & \multirow{3}{*}{$0,027^{*}$} \\
\hline More than $60 \mathrm{~Gy}$ & $3(100,0)$ & $2(18,2)$ & $5(35,7)$ & \\
\hline Total & $3(100,0)$ & $11(100,0)$ & $14(100,0)$ & \\
\hline \multicolumn{5}{|l|}{ Fractionation } \\
\hline Up to 33 sessões & $0(0,0)$ & $8(72,7)$ & $8(57,1)$ & \multirow{3}{*}{$0,055 *$} \\
\hline More than 33 sessões & $3(100,0)$ & $3(27,3)$ & $6(42,9)$ & \\
\hline Total & $3(100,0)$ & $11(100,0)$ & $14(100,0)$ & \\
\hline \multicolumn{5}{|l|}{ Duration (weeks) } \\
\hline Up to 8 weeks & $1(33,3)$ & $7(63,6)$ & $8(57,1)$ & \multirow{3}{*}{$\mathbf{0 , 3 8 5}$} \\
\hline More than 8 weeks & $2(66,7)$ & $4(36,4)$ & $6(42,9)$ & \\
\hline Total & $3(100,0)$ & $11(100,0)$ & $14(100,0)$ & \\
\hline
\end{tabular}

* - Fisher's Exact Test. Fonte: Statistical Package for the Social Sciences (SPSS 20).

The presence of tobacco use was also analyzed. It was noticed that $6(54.5 \%)$ patients with periodontitis had a tobacco habit and $5(45.5 \%)$ participants did not have this associated habit. On the other hand, in relation to gingivitis only, 1 individual (33.3\%) had this associated habit, while the other $2(66.7 \%)$ patients did not. There was no statistically significant association between the presence of periodontitis and the habit of tobacco consumption $(\mathrm{p}=1.000)$ (Table 4$)$.

Table 4 - Analysis of periodontal condition in relation to the presence of a smoking habit. Natal / RN, 2016.

\begin{tabular}{|c|c|c|c|c|}
\hline \multirow{2}{*}{ Smoking } & \multicolumn{2}{|c|}{ Periodontal Condition } & \multirow{2}{*}{ Total } & \multirow{2}{*}{$p^{*}$} \\
\hline & Gingivitis & Periodontitis & & \\
\hline Yes & $1(33,3)$ & $6(54,5)$ & $7(50,0)$ & \\
\hline No & $2(66,7)$ & $5(45,5)$ & $7(50,0)$ & 1,000 \\
\hline Total & $3(100,0)$ & $11(100,0)$ & $14(100,0)$ & \\
\hline
\end{tabular}

\footnotetext{
* - Fisher's Exact Test. Fonte: Statistical Package for the Social Sciences (SPSS 20).
} 
The presence of gingivitis only and periodontitis was also associated with the primary tumor site. Of the 11 participants with periodontitis, 7 (63.6\%) had primary tumors in the oral cavity, while $4(36.4 \%)$ had primary tumors in the other head and neck regions. Of the 3 patients with gingivitis only $1(33.3 \%)$ had the tumor in the oral cavity and the other $2(66.7 \%)$ had the tumors in the other head and neck regions. No statistically significant associations were found $(\mathrm{p}=0.385)$ (Table 5).

Table 5 - Comparison of the periodontal condition with the tumor origin site. Natal / RN, 2016.

\begin{tabular}{ccccc}
\hline $\begin{array}{c}\text { Place of Tumor } \\
\text { Origin }\end{array}$ & \multicolumn{2}{c}{ Periodontal Condition } & Total & $\boldsymbol{p}^{*}$ \\
\cline { 2 - 3 } Oral Cavity & Gingivitis & Periodontitis & & \\
Other Head and & $1(33,3)$ & $7(63,6)$ & & \\
Neck Regions & $2(66,7)$ & $4(36,4)$ & $6(42,9)$ & $\mathbf{0 , 3 8 5}$ \\
Total & $3(100,0)$ & $11(100,0)$ & $14(100,0)$ & \\
\hline
\end{tabular}

* - Fisher's Exact Test. Fonte: Statistical Package for the Social Sciences (SPSS 20).

Furthermore, the most prevalent debilitating condition was oral mucositis. It was found that 7 (63.6\%) members with periodontitis had some degree of mucositis, while 4 (36.4\%) did not have this condition. No significant association was found between the presence of periodontitis and mucositis $(\mathrm{p}=0.505)$ (Table 6$)$.

Table 6 - Association between periodontitis and the presence of mucositis. Natal / RN, 2016.

\begin{tabular}{rcccr}
\hline \multirow{2}{*}{ Mucositis } & \multicolumn{2}{c}{ Periodontal Condition } & Total & $p^{*}$ \\
\cline { 2 - 4 } & Gingivitis & Periodontitis & & \\
\hline Yes & $3(100,0)$ & $7(63,6)$ & $10(71,4)$ & $\mathbf{0 , 5 0 5}$ \\
N0 & $0(0,0)$ & $4(36,4)$ & $4(28,6)$ & $14(100,0)$ \\
\hline Total & $3(100,0)$ & $11(100,0)$ & \\
\hline
\end{tabular}

* - Fisher's Exact Test. Fonte: Statistical Package for the Social Sciences (SPSS 20).

\section{Discussion}

Radiotherapy is a therapeutic modality which can be used together or as a primary treatment for head and neck neoplasms (Krstevska, 2009; Khaw, et al., 2014). However, its performance is not restricted to tumor tissue, but also affects healthy tissues which results in adverse reactions, including tissues from the oral cavity and the periodontium (Beech, et al., 2014). For this reason, the objective of this research was to evaluate the influence of head and neck radiotherapy on the periodontal condition and oral hygiene of patients undergoing ionizing radiotherapy. 
Most of the research patients had head and neck tumors during the $5^{\text {th }}$ and $6^{\text {th }}$ decades of life, with a predominance of incidence in male patients. These data corroborate the studies by Toporcov et al. (2015), Andrade et al. (2015) and Zhang et al. (2016), who describe that male patients between the $5^{\text {th }}$ and $8^{\text {th }}$ decades of life are the main risk group for tumors in the head and neck region. Regarding habits, it was found that the highest occurrence of tumors occurred in patients who were smokers, consumed alcohol or associated consumption of tobacco and alcohol, which is in agreement with epidemiological studies presenting data indicating that these habits are risk factors for head and neck tumors (Scully, et., 2009; Andrade, et al., 2015; Toporcov, et al., 2015; Potter, et al., 2016).

The VPI was used to verify the oral hygiene condition. This index and the GBI of the evaluated patients showed no significant changes between baseline and collection immediately after radiotherapy. However, in the study by Ammajan et al. (2013), patients' VPI increased 6 months after completing radiotherapy. This difference may be explained by the dental follow-up that LNRCC patients receive during and immediately after radiotherapy treatment, which also corroborates the study by Bueno et al. (2013) in which patients presented a decrease in VPI due to dental follow-up given to patients during radiotherapy treatment, and which may also justify the small improvement in the oral hygiene quality of patients after radiotherapy. Similarly, the GBI data from the present study contradict the studies by Ammajan et al. (2013); Marques et al. (2004); and Khaw et al. (2014), who found an increase in this index. This difference may have been caused by the dental follow-up of patients by LNRCC during radiotherapy and by the short time between the two data collections. It is possible that differences will be found between the gingival bleeding and visible plaque rates with a longer time interval of 6 to 24 months between the evaluations. Also, the VPI and the GBI possibly better reflect the oral hygiene condition of patients when there is greater spacing between dental consultations in the LNRCC.

The oral hygiene condition of most evaluated individuals was still unsatisfactory after radiotherapy, even with the slight improvement in patient hygiene. In addition to periodontal changes, reactions in other tissues of the stomatognathic system may affect the quality of patient hygiene, such as trismus, hyposalivation and mucositis (Epstein, et al., 2001; Marques, et al., 2004; Ammajan, et al., 2013; Khaw, et al., 2014). Moreover, a lack of physical and emotional motivation can also negatively influence patients' oral hygiene (Marques, et al., 2004; Ammajan, et al., 2013).

Regarding the total radiotherapy treatment time, there was no influence of treatment time on periodontal condition and oral hygiene. These data corroborate the results of Khaw et al. (2014), who only found an influence of total radiotherapy treatment time on the severity of oral mucositis. Ammajan et al. (2013) and Marques et al. (2004) indicate the final dose and the irradiated region as being the most determining factors for periodontal changes resulting from radiotherapy.

In this sense, although this study did not find a significant association between radiation site and periodontitis, periodontal disease showed higher prevalence in patients with primary tumors in the oral cavity. Marques et al. (2004) and Ammajan et al. (2013) found a significant relationship between the irradiated area and the loss of CAL in the maxilla, suggesting that the maxilla periodontium is more susceptible to the influence of radiation. Thus, it is possible that there is a difference in the development of periodontitis according to the irradiated area.

Similarly, the periodontal condition after patients' radiotherapy was not influenced by fractionation and radiation dose. This is attributed to the short interval between the two data collections. Monroe et al. (2016) and Khan et al. (2016) stated that the periodontal condition undergoes changes with doses higher than 25 Gy after 6 months of follow-up in patients after completing radiotherapy. Major periodontal changes were found over the course of 12 months in this study. The results found may also differ due to the sample size, which proved to be a limitation of the study. It is possible that the results may be more similar with increasing the sample. Fractional data related to periodontitis and gingivitis only corroborate those by Ammajan et al. (2013), who found a 
significant difference only in the relationship between gingival recession and fractionation over 20 mandible sessions after 6 months of follow-up.

The participants in this study were divided in relation to the radiation dosage received up to $60 \mathrm{~Gy}$ and more than $60 \mathrm{~Gy}$, as this value is the median of the sample, and is similar to the study by Marques et al. (2004). In the study by Monroe et al. (2016), it was observed that the periodontium suffers damage when exposed to doses from 25 Gy in a follow-up for 2.5 years. It was not possible to establish this value because all evaluated patients received doses above $40 \mathrm{~Gy}$ and the follow-up was only until the completion of radiotherapy.

Radiation from radiotherapy causes changes in the periodontal which may manifest months or years after treatment. Changes in vessels such as obliterative endarteritis, which reduce blood flow in supporting tissues, increase the susceptibility of periodontal diseases by decreasing defensive efficiency (Ammajan, et al., 2013; Khaw, et al., 2014). Fibrosis is formed in the connective tissue of the periodontium, promoting a decrease in the number of cells in the periodontal tissue caused by radiotherapy which may lead to a decrease in the proliferative and regenerative capacity of the periodontium after a few months (Ammajan, et al., 2013). In addition, decreased cell count leads to thinning and rupture of periodontal tissue. Since these changes have been considered late, it is possible that periodontal changes may manifest more intensely in a long-term follow-up of patients (Epstein, et al., 2001).

In addition, periodontitis and oral mucositis have been considered as events which share common regulatory mechanisms. It was hypothesized that these two conditions were interrelated by the dysregulation of the inflammatory response caused by ionizing radiation (Khaw, et al., 2014). Even though mucositis is characterized by an acute inflammatory manifestation and periodontitis a chronic manifestation, both share co-expression of cytokines such as IL-1, IL-6 and TNF- $\alpha$, as well as TGF- $\beta$ expression. Each of these inflammatory diseases may precondition the individual to develop the other (Khaw, et al., 2014).

Clinical diagnosis of periodontal disease is based on measuring probing depth, ISG, CAL and loss of bone support. However, studies use varied clinical parameters to diagnose periodontitis (Bueno, et al., 2013). In addition, different ways of assessing the affected teeth are also used from periodontal probing and measuring the CAL of all elements, of some selected elements, in the element most affected by sextant or quadrant disease or index teeth. These measurements can also be performed at 2, 4 or 6 sites per tooth. Thus, the comparison between results of different studies may be hampered by the difference between the definitions of periodontal disease diagnosis (Martin, et al., 2013).

Ammajan et al. (2013) used 4 collection sites on all teeth measuring probing depth, GBI, VPI, CAL and gingival recession to diagnose periodontal disease, while Bueno et al. (2013) only used VPI, GBI, probing depth and CAL at 6 points per tooth, classifying periodontitis levels according to CAL and periodontal probing.

On the other hand, Schuurhuis et al. (2011) only used probing depth and radiographic examination at different collection times to assess alveolar bone loss to diagnose periodontitis. In their study comparing various definitions for the diagnosis and measurement of periodontitis, Bueno et al. (2013) concluded that determining 4 or more teeth with at least one site with $3 \mathrm{~mm}$ or more loss at CAL and 4 or more teeth with $4 \mathrm{~mm}$ or more probing depth was the most accurate criterion for the case definition of periodontitis in head and neck cancer patients.

\section{Conclusion}

It was possible to observe that the dental follow-up during the radiotherapy treatment enabled maintaining the existing periodontal condition. There was also a tendency to develop periodontitis in participants who presented tumors in the oral cavity 
region and received radiation directly over this area. The development of gingivitis only and periodontitis was not influenced by the dose, fractionation or duration of radiotherapy during the study period, although the dose tended to aggravate periodontal disease in patients who received more than 40Gy. Thus, other studies comprising larger samples, longer follow-up periods, with more radiotherapy sessions and different radiation doses are suggested in order to better understand this influence on periodontal tissue. Standardization in the different studies is paramount for a better evaluation and comparison of the data found in the different studies.

\section{Conflicts of interest}

The authors declare that they have no conflict of interest.

\section{Ethical approval}

All procedures performed in the study involving human participants were in accordance with the ethical standards of the institutional and/or national research committee (Research Ethics Committee of the Northeriograndense League Against Cancer) and with the 1964 Helsinki declaration and its later amendments or comparable ethical standards.

\section{Informed Consent}

Informed consent was obtained from all individual participants included in the study.

\section{References}

Ainamo, J.; Bay, I. (1975). Problems and Proposals for Recording Gingivitis and Plaque. Int. Dent. J., 25(4), 229-235.

Ammajan, R. R., Joseph, R., Rajeev, R., Choudhary, K., \& Vidhyadharan, K. (2013). Assessment of periodontal changes in patients undergoing radiotherapy for head and neck malignancy: a hospital-based study. Journal of cancer research and therapeutics, 9(4), 630-637.

Andrade, J. O. M.; Santos, C. A. S. T.; \& Oliveira, M. C. (2015). Associated Fators With Oral Cancer: A Study of Case Control in A Population of Brazil's Northeast. Rev. Bras. Epidemiol, 18(4), 894-905.

Beech, N., Robinson, S., Porceddu, S., \& Batstone, M. (2014). Dental management of patients irradiated for head and neck cancer. Australian dental journal, 59(1), $20-28$.

Bhide, S. A., \& Nutting, C. M. (2010). Advances in radiotherapy for head and neck cancer. Oral Oncol, 46(6), 439-441.

Bueno, A. C., Ferreira, R. C., Barbosa, F. I., Jham, B. C., Magalhães, C. S., \& Moreira, A. N. (2013). Periodontal care in patients undergoing radiotherapy for head and neck cancer. Supportive care in cancer: official journal of the Multinational Association of Supportive Care in Cancer, 21(4), 969-975.

Duarte, V. M., Liu, Y. F., Rafizadeh, S., Tajima, T., Nabili, V., \& Wang, M. B. (2014). Comparison of dental health of patients with head and neck cancer receiving IMRT vs conventional radiation. Otolaryngology--head and neck surgery: official journal of American Academy of Otolaryngology-Head and Neck Surgery, 150(1), $81-86$.

Epstein, J. B.; \& Stevenson-Moore, P. (2001). Periodontal Disease and Periodontal Management in Patients with Cancer. Oral Oncol., 37(8), 613-619.

Hong, C. H., Napeñas, J. J., Hodgson, B. D., Stokman, M. A., Mathers-Stauffer, V., Elting, L. S., Spijkervet, F. K., Brennan, M. T., \& Dental Disease Section, Oral Care Study Group, Multi-national Association of Supportive Care in Cancer (MASCC)/International Society of Oral Oncology (ISOO) (2010). A systematic review of dental disease in patients undergoing cancer therapy. Supportive care in cancer: official journal of the Multinational Association of Supportive Care in Cancer, 18(8), 1007-1021.

Khan, S., Feroz, S., Jain, M., Mathur, V., \& Khan, S. (2016). Effect of Fractionated Dose of Radiotherapy on Oral Mucosa in Head and Neck Cancer Patients: A Cytological Assessment. The Gulf journal of oncology, 1(21), 30-35.

Khaw, A., Liberali, S., Logan, R., Keefe, D., \& Bartold, P. M. (2014). Influence of periodontitis on the experience of oral mucositis in cancer patients undergoing head and neck radiotherapy: a pilot study. Supportive care in cancer: official journal of the Multinational Association of Supportive Care in Cancer, 22(8), 21192125. 


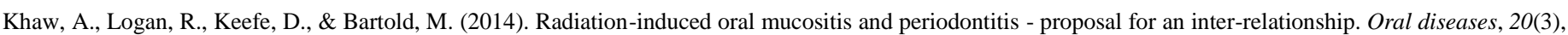
e7-e18.

Krstevska, V. (2009). Radiotherapy and Chemotherapy in Locally Advanced Head and Neck Squamous Cell Carcinoma. J. Buon., 14(3), 361-373.

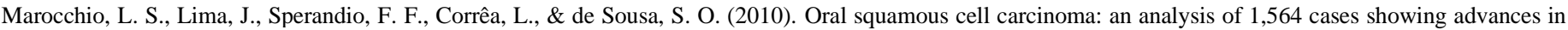
early detection. Journal of oral science, 52(2), 267-273.

Marques, M. A., \& Dib, L. L. (2004). Periodontal changes in patients undergoing radiotherapy. Journal of periodontology, $75(9), 1178-1187$.

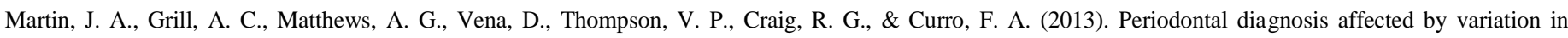
terminology. Journal of periodontology, 84(5), 606-613.

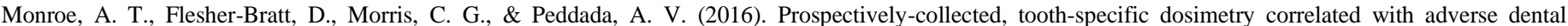
outcomes. Oral surgery, oral medicine, oral pathology and oral radiology, 122(2), 158-163.

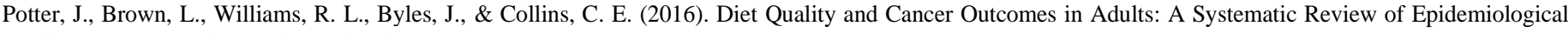
Studies. International journal of molecular sciences, 17(7), 1052.

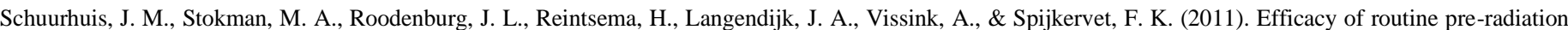

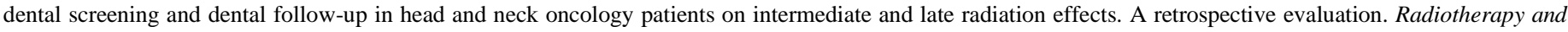
oncology: journal of the European Society for Therapeutic Radiology and Oncology, 101(3), 403-409.

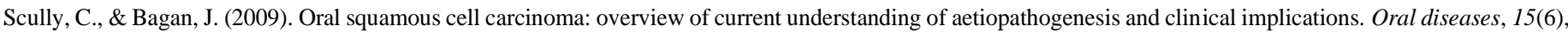
388-399.

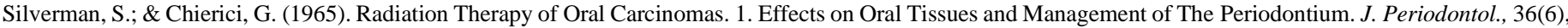
478-484

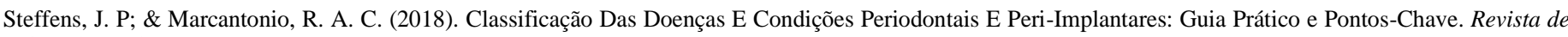
Odontologia da Unesp, 47(4), 189-197.

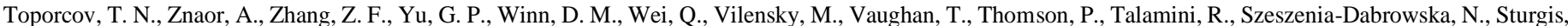

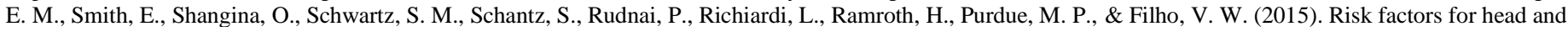
neck cancer in young adults: a pooled analysis in the INHANCE consortium. International journal of epidemiology, 44(1), 169-185.

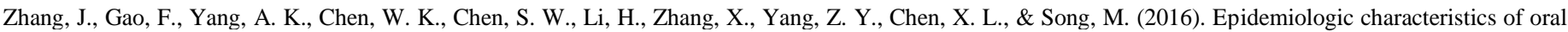
cancer: single-center analysis of 4097 patients from the Sun Yat-sen University Cancer Center. Chinese journal of cancer, $35,24$. 